\title{
ORAÇÕES PARA UM ATEU NA UTI DA COVID-19: GRATIDÃO E REFLEXÕES
}

Prayers for an atheist in the Covid-19 UCI: gratitude and reflections

Reginaldo Melhado ${ }^{1}$

Londrina, 26 de maio, dez e meia da noite. Recebi com tranquilidade o último teste feito pela farmácia naquela noite. Paguei a conta, agradeci e dei boa noite ao rapaz com tranquilidade. Entrei no carro e antes de partir avisei familiares e amigos mais próximos. Isolei-me no que era já solitude: minha casa, onde vivia solitário. Em 4 de junho a coisa não estava boa e fui internado. Quatro dias mais tarde, estava na UTI do Hospital Evangélico, onde permaneceria por 11 infinitas noites. $\mathrm{O}$ vidro fosco me tomara de assalto os pulmões rapidamente e estima-se que 80 ou $90 \%$ deles chegaram a estar invadidos pelos destacamentos impiedosos do coronavírus. Voltei para casa em frangalhos, ainda com 75\% do grande e vital órgão respiratório sob o domínio inclemente da inflamação viral, em internação domiciliar, agora pendurado na máquina de oxigênio. Esse é resumo da história, cuja experiência quero contar em outra ocasião.

Durante essa tormenta, borbotões de mensagens brotavam em meu celular. Escreviam-me pessoas de meus muitos nichos de relacionamento: familiares próximos e mais distantes, gente da magistratura, companheiros da bike, colegas de magistério na universidade, amigos de infância, colegas de turma. Gente com quem convivo e gente querida que se perdera de minhas retinas desfalecidas faz décadas. Companheiros e adversários de lutas e disputas teóricas, políticas e ideológicas. Gente que me ama, gente que nem me gosta. Até uma pessoa que disse certa vez odiar-me, com áscuas de cólera disparadas de seus lindos olhos de modo certeiro, fazendo-me arder os ossos até hoje. Todas essas pessoas diziam estar orando por mim.

Escrevo aqui para agradecer a cada uma delas. Deveria responder individualmente, dizendo-lhes então as palavras de agora. Naqueles momentos, porém,

\footnotetext{
${ }^{1}$ Reginaldo Melhado, 59 anos, professor da Universidade Estadual de Londrina. É doutor em Teoria Geral e Filosofia do Direito (Universidade de Barcelona/USP), juiz da $6^{\text {a }}$ Vara do Trabalho de Londrina e membro da Associação Juízes para a Democracia.
} 
não me restavam energias, nem raciocínio, nem nada. Garatujei para alguns o muito obrigado da convenção. Gostaria de falar com cada uma dessas pessoas, mas já não dá. Tenho receio de alguém me escapar à memória, e a exclusão de uma só delas seria ultraje inaceitável. Assim, mesmo sendo genérica, gostaria de fazer esta minha fala chegar na intimidade de um diálogo individual impossível e simbólico.

Sou ateu. Às vezes, imagino ter nascido com esse aleijão imemorial. Millor Fernandes disse uma vez que o cara só é verdadeiramente ateu enquanto está bem de saúde. Não mudei nem mesmo vendo a morte tão perto. Por isso quero explicar e dizer como estou sinceramente grato por tantas orações, vindas de gentes de tantas diferentes religiões.

Suponho ser a oração pela saúde e pela vida de outra pessoa a mais sublime experiência em qualquer religião. Também o é para um ateu. A pessoa não reza para si mesma. Não quer pagar dívidas nem arrumar emprego, ou resolver seus próprios tormentos com saúde, relacionamentos afetivos, moradia ou todo o mais. Nesse momento único, a súplica se eleva por sobre nossa sociedade desigual, de exploração de classe e de apropriação sempre mais intensa da mais-valia, de consumo doentio de bens pressupondo o do próprio ser, de arrivismo, de permanentes disputas pelo mercado, pelo emprego, pela performance individual e pela promoção. Tudo isso dá lugar a uma viagem irrepetível: solidariedade, empatia, caridade, altruísmo, compaixão, despojamento. Para o cristianismo, o ser humano é Deus, pois criado à sua imagem e semelhança, e portanto com Ele se funde e confunde. Essa fusão transcendente, porém, se esvanece pelo livre arbítrio de que é dotado, e mais ainda por serem sua consciência e apreensão da realidade determinadas social e historicamente. Assim, nos demais momentos de sua vida deus está morto e a pessoa é apenas parte da sociedade de classes, toda ela o avesso da oração pelo Outro. Talvez não haja nada mais antípoda em face da sociedade destrutiva e iniqua na qual nos metemos cada vez mais fundamente: a oração aqui é revolucionária.

A oração cura um doente ateu? A força dessa energia interna, vital ou cósmica, derivada desse orar, é ainda desconhecida pela ciência em quase toda sua totalidade. Para alguns filósofos, talvez a cura seja sim possível. Aristóteles e Platão cogitam disso, ao tratar do "nous". A filosofia budista igualmente, e de modo mais radical, pois para ela o pensamento cria e conforma o real. Outras tantas correntes filosóficas vão mais ou menos por essa estrada. Estudos e ensaios clínicos contemporâneos de neurocientistas investigam como neurônios podem produzir energias - ou são energia em si mesmos capaz de interferir no real, inclusive e especialmente no campo da saúde humana. 
Por isso tudo, creio terem sido as orações parte do resgate de um ateu. Por isso, mas não apenas pelo resultado de estar vivo, escrevendo, agradeço por suas orações do fundo de meu espírito, sempre irrequieto, mas também sereno e reconfortado. Fique com Deus, com Alá, com o Poder Absoluto, com Nous, com ou no Nirvana, com Brama, Vishnu e Shiva, com Shangdi e com todos santos e orixás. Axé. Amém.

A gratidão permanecerá nas profundezas de minha renascida eternidade de mais algum tempo. 